\title{
CULTURAL APPROACHES IN CYBERPORN CRIME PREVENTION
}

\author{
Prima Angkupi \\ Faculty of Law Universitas Muhammadiyah Metro, Indonesia \\ E-mail: prima.blecbelt@gmail.com
}

\begin{abstract}
Limitations of law in cyberporn law enforcement demands the need for non-penal approach as preventive effort to eliminate causes of Cyberporn crimes. This approach includes crime prevention which aims to prevent a crime from being recurred. This approach can be implemented through situational control by active involvement of cultural roles in community. However, it cannot be separated from observing human life variations including childhood, youth, family, school, gender, peer group which play significant role during productive period. Those variations cane be taken as a theoretical base for cyberporn crime prevention.
\end{abstract}

Key words: pornography, internet, crime prevention

\begin{abstract}
Abstrak
Keterbatasan hukum dalam penegakan hukum cyberporn menuntut perlunya upaya dengan menggunakan pendekatan non penal secara lebih maksimal, karena dapat menghilangkan dan menghapuskan sebab-sebab terjadinya kejahatan. Pendekatan dengan cara non penal mencakup area pencegahan kejahatan (crime prevention). Konsep pencegahan kejahatan merupakan tindakan dalam bentuk konkrit untuk mengurangi atau menghentikan faktor penyebab terjadinya kejahatan tersebut sehingga akan mencegah kejahatan tersebut muncul kembali. Bentuk pencegahan yang dapat dilakukan adalah melalui pengendalian situasional serta melibatkan pembentukan peran kultur masyarakat. Proses tersebut tidak terlepas dari mempelajari variasi hidup manusia dari masa kanak-kanak atau remaja, keluarga, sekolah, keluarga, gender, kelompok sebaya (ikatan sosial), yang sangat berperan ketika masa produktif individu. Bentuk-bentuk variasi hidup tersebut dapat dilakukan sebagai landasan teoritik pencegahan kejahatan cyberporn.
\end{abstract}

Kata kunci: pornografi, internet, pencegahan kejahatan

Introduction

Cybercrime is a condition associated with criminal activity using a computer or computer network as a means. ${ }^{1}$ Cyberporn is a form of cybercrime which causes unrest and dangerous in society. Pornographic content via the Internet circulated widely both in the real world and in cyberspace. This happens since accessing the Internet through an Internet cafe, laptops, computers, and mobile phones is so easy. Therefore, repressive countermeasures is difficult to do. The existence of law is not effective in tackling pornography, especially the Internet presence that can expand and facilitate access

Dian Rachmawati, "Phising Sebagai Salah Satu Bentuk Ancaman Dalam Dunia Cyber", Jurnal SAINTIKOM, Vol. 13 No. 3, September 2014, Medan: STMIK Triguna Dharma, page 210 . to pornography. ${ }^{2}$ This limitation requires the necessity of penal law enforcement by using a non penal approach more effectively to eliminate the causes of crime. Non penal approach includes the area of crime prevention. Crime prevention is basically the main purpose of the criminal policy. This is because pornography is not only about moral issues, culture and human rights but also a matter of economics, business, entertainment and politics. Therefore, in cyberporn prevention, policy required legal construction that can counteract the negative impact of the multi problems. Building and construction law in the form of people's contribution organize an effective response.

2 Dewi Bunga, "Penanggulangan Pornografi dalam Mewujudkan Manusia Pancasila", Jurnal Konstitusi, Vol. 8 No. 4, 2014, Jakarta: Mahkamah Konstitusi, page 44. 
Stage in crime prevention is a prediction that foresees the occurrence of crime accompanied by in-depth analysis of the factors that cause cyberporn crime. Next is intervention by implementing efforts to stop the proliferation of the crime causes. In crimes cyberporn, internet media is like a big business to earn huge profits as there are many consumers who use them. The analysis of this intervention is associated with a culture of compliance in the community. By restoring or constructing the legal culture of the public not to consume cyberporn, it will stop cyberporn media itself. Therefore the legal culture still plays an important role in stopping crime. In accordance with its development, there are three approaches in crime prevention strategies namely social crime prevention, situational crime prevention, and community-based crime prevention.

Prevention of crime basically tries to find the force that drives the occurrence of crime. ${ }^{3}$ Social control by the government is essential in preventing crime. The process cannot be separated from human life variations including childhood, youth, family, school, gender, and peer group which play significant role during productive period. Dealing with various forms of theoretical cyberporn crime prevention, there are some patterns for actual implementation.

\section{Discussion \\ Situational Crime Prevention Through Tech- nology}

Cyberporn is a crime that uses the technology. Therefore, control must involve technological approaches, as a strategic step in the prevention of criminal acts cyberporn. Identification technology is a rational action to complicate deployment cyberporn crimes. Cyberporn deploy sites or pornographic material systematically use information technology and electronic media.

Muhammad Kemal Darmawan, "Pencegahan Kejahatan: dari Sebab-Sebab Kejahatan Menuju Pada Konteks Kejahatan", Jurnal Kriminologi Indonesia, Vol. 1 No. 3, July 2012, Jakarta: Department of Crimonology, Faculty of Social and Political Sciences Universitas Indonesia, page 36.
Internet access is also potential for the consumption of pornography in addition to the cafe are computers in companies that provide internet network for their employees. This happens due to several factors, such as free internet facility, to relieve boredom of work/ stress, and their sexual disorder or addiction to pornography. This ultimately resulted in dependency and destructive implications ${ }^{4}$ in terms of personal well-being, social adaptation, employment, sex life and family relationships.

Presidential Decree Number 6 Year 2001 stipulates Policy Framework for Development and Utilization of Telematics Technology (ICT). It explains that internet cafes are at the forefront in achieving the desired objectives in addition to the kiosk. Thus the technology information through the Internet has unstoppably penetrated into areas. In addition to leading the empowerment of information technology and telecommunications, internet cafes is also a cornerstone for the audience of porn sites. ${ }^{5}$

Optimizing the rules should also be increased to suit the purpose, because the pornographic website can be created by anyone and can be used by anyone, wherever they are and without any supervision. ${ }^{6}$ With legal basis Regulation of the Minister of Communication and Information Number 19 Year 2014 on Handling Negative Charged Internet site, the government now authorizes to block porn sites. The Minister's decision should be made effective given the blocking efforts to date only $0.1 \%^{7}$ filter pornographic content via the internet. Instead,

4 Gabriel Cavaglion, "Cyber-porn Dependence: Voices of Distress in an Italian Internet Self-Help Community", International journal of mental health and addiction, Vol. 7 No. 2, April 2009, Auckland University of Technology; West Virginia University. Dept. of Behavioral Medicine \& Psychiatry, Springer Verlag, page. 205.

5 Novita, "Budaya Hukum Cyberporn di Semarang", Jurnal Pandecta (research law journal), Vol. 7 No. 2. July 2012, Semarang: Faculty of Law Universitas Semarang, page 182.

6 Alfons Zakaria, "Pelarangan Website Yang Bermuatan Pornografi di Indonesia (The Restriction of Websites Containing Pornography Materials in Indonesia", Risalah Hukum: Jurnal Hukum, Vol. 7 No. 1, June 2011, Samarinda: Faculty of Law Universitas Mulawarman, page 12.

7 Mas Wigrantoro Roes Setiadi (Sekretaris Jenderal Masyarakat Telematika), Budaya pornografi di Indonesia, available on https://www. selasar.com, accessed on November $30^{\text {th }} 2015$. 
the government through the Minister of Religion focuses on the contents of Radical Islam.

The use of technology approach requires further study and research on the internet information technology. A deeper research is required to create technology that is relatively inexpensive and overcome these problems, in addition to the awareness of ISPs (Internet server providers), owners of the cafe (internet cafes) and users themselves. Safety regulations in the fight against computer crime especially cyberporn already existed in Indonesia. Regulation of the Minister of Communication and Information Number 27/PER/M.KOMINFO/9/2006 on the use of Internet-based telecommunications network has been set up on internet regulation. Article 10 Regulation of the Minister of Communication and Information Number 27/PER/M.KOMINFO/ 9/2006 requires the recording of transaction activity connections (Log File) against the organizers of internet access (internet server provider/ ISP) and internet cafes which are resellers of ISP (Internet server provider) which has a provision of internet services to the public.

Crime prevention through controlling the situational demands the government to take an active role in the dissemination of the cultural approach in the community and should be supported by public awareness, cooperation and all parties, including government, internet service providers (internet server provider), internet cafes, educational institutions, communities, parents, internet users (user) and national and international cooperation.

\section{Age and Cyberporn Prevention}

Adolescence is an influential factor in determining individual behavior. Elements animated images in pornography exploit negative imagination of teenagers and children. Cyberporn can induce other crimes. ${ }^{8}$ Cyberporn gives impressive scene for teenagers who are immature to consider the level of rationality. These impacts exacerbate the social interaction of

\footnotetext{
8 Amirudin Y Dako, "Pengaturan hukum Tindakan Teknologi Pornografi Melalui Akses Media Internet", Jurnal Legalitas, Vol. 2 No. 3, 2009, Gorontalo: Department of Law, Universitas Negeri Gorontalo, page 68.
}

teenagers towards the environment. Cyberporn is like an addictive substance. Cyberporn addiction is a repetitive behavior to see things that stimulate the sexual desire that can damage a person's brain health because they cannot stop it. ${ }^{9}$ Damage to the brain function results in decreased learning ability and decision-making, so that the impact of impressions cyberporn is more dangerous than addictive. ${ }^{10}$

According to criminology perspective, children or adolescent should be introduced to positive ritual things. The mutual influence between the individual and the environment led to interest in adolescents and children to new events. In order to motivate curiosity finally be out of their reach, it seemed plausible motivation for them. In the course of this development the role of all the parties provide a positive model of motivation for them. One form is deeprooted in advance with positive behavior by giving the consequences of reward and punishment. Model construction can form a child's immoral behavior of individuals when they are adults.

The process of moral reasoning of children and youth starts from: First, a strong social bond on the environment, family, school. Moral reasoning to model the consequences will shape the character's behavior, thus prepare the child in the influence of Internet media, especially pornography so that they naturally filter any negative contents. Second, externally, the consequences of reasoning would increase the maturity and responsibility; anticipation done early on moral reasoning will be repeated habit encountered during adulthood. Third, the embedded social environment and lifestyle makes teenagers become more likely the interaction behavior of conspecifics. A habit that has

9 Kandi Aryani, "Analisis Penerimaan Remaja terhadap Wacana Pornografi dalam Situs-Situs Seks di Media Online", Jurnal Masyarakat Kebudayaan dan Politik, Vol/ Year XIX. No. 2, 2006, Surabaya: Faculty of Socoal and Political Science Universitas Airlangga, page. 5.

10 Elly Risman, Mark B Kastleman, Randall F Hyde, Malik B Badri, “Membangun Kesadaran Betapa Dahsyatnya Kerusakan Kesehatan Otak Akibat Perilaku Adiksi Pornografi", Pidato Seminar, International Seminar and Workshop, Jakarta, Hotel Grand Kemang, Monday, September $27^{\text {th }} 2014$. 
been arranged into a symbol of a part of the character of individual life.

Creating moral reasoning in children and adolescents can change individual personality becomes a social self through a process of socialization and interaction among individuals. The above analysis makes a benchmark for construction of individual behavior of children and adolescents. Thus by the achievement of a pattern or model the behavior, children or teenagers are able to anticipate or face social deviation and will directly be ready to face any form of crime cyberporn or other irregularities.

This approach is strengthened by the constitutional arrangements on the protection and welfare of children as stipulated in article 18 paragraph (2) of the Constitution that children have a right to live, grow and develop and is entitled to protection from violence and discrimination. Therefore, the formation of the cultural conditions of society from an early age should be a priority of the government, especially in the construction of the legal culture. The government through the Indonesian Child Protection Commission may be guardians and protectors of children of their rights in order to live, grow, develop and participate optimally in accordance with the dignity of humanity under Law Number 35 Year 2014 on Children Protection. Consequently, cyberporn crime prevention efforts can walk through a policy that corresponds to the target.

\section{Gender Differences and Cyberporn Prevention}

In modern society, limit deviations due to gender in crime becomes close. The reasons for the psychological, social, and physical factors in reality shows there is an imbalance between men and women to find opportunities to commit a crime. Generally, crime is male-dominated, active and aggressive. ${ }^{11}$ Therefore, the formation of individual character should be directed to men. Cyberporn crimes are generally committed by men. Extension cyberporn impact should be focused among men.

11 Frank Hagan, 2013. Pengantar Kriminologi: Teori, Metode, dan Perilaku Kriminal, Jakarta: Kencana Prenada Media Group, page 93.
Male gender in bio-criminological perspective shows more susceptible to access cyberporn for biological factors. Louann Brizendine, M.D $D^{12}$ suggests that the brains of men and women have a sexual pursuit area named hypothalamus. Sexual pursuit area at the hypothalamus in males measures 2.5 times greater than in women, so the male hormone testosterone produces ten times higher.

In addition, research from Emory University, Atlanta found a trend that the amygdala, a part of the brain that controls emotion and motivation, is more active work in men compared with women after being exposed pornography for 30 minutes. ${ }^{13}$ The biological behavior showed a greater proportion of men. The possibility of larger deviations, especially against cyberporn the male lead heeling criminal behavior. Changes in the concept of individual criminology thought should prioritize gender male cyberporn in preventing crime. Chiara Sabina ${ }^{14}$ expressed boys are more likely to be exposed at an early age to consume cyberporn. The inclination of deviation can estimate cyberporn crime through gender classification, the demands of crime prevention should adjust to developments and patterns of appropriate precautions. By doing so, the extension code of values and norms must give priority to the potential perpetrators, are male.

The effort is the scope of actions that can minimize the impact of crime cyberporn. As expressed by Fisher ${ }^{15}$, that the reduction of opportunities as well as giving effect to the people who potentially committed a crime is a serious form of crime prevention that can be done in various ways. The concept of community policy

12 Louann Brizendine, "Penulis buku The Male Brain" ( $E$ Harmoni staff, Inside 'The Male Brain'), available on http: / / www.eharmony.com accessed on April $20^{\text {th }} 2015$.

13 J.R. and M.M.S, Maturing brain flips function of amygdala in regulating stress hormones, The Journal of Neuroscience, Vol. 34 No. 34, August 2014, Washington: Stanford University's, pages 11452-11460.

14 Chiara Sabina, Janis Wolak, David Finkelhor, "The Nature and Dynamics of Internet Pornography Exposure for Youth, journal of CyberPsychology \& Behavior”, Vol. 11 No. 6, December 2008, USA: Mary Ann Liebert, inc, page 691.

15 Robert J. Fisher and Gion Green, 1998, Introduction to Security. USA: Elsevier Science USA, Butterworth Heinemann, page 144 . 
is a partnership program the public can better pursue socialization and counseling character in accordance with public order (especially lacquers men in crime prevention cyberporn). Thus it improves the performance of national police as indispensable as the protector of people's behavior through good communication.

\section{Family and Cyberporn Prevention}

Family is the first form of social bonding in encouraging individual behavior. Socialization behavior by individual character is very instrumental with the family, especially the exclusive contact between children and parents. Internal control families through improved family functioning, family communication is an attempt of character formation, law-abiding society. In cyberporn crimes, the readiness of a community is needed to face deviation using technology. Morality in the family will give effect to the social forces external to the cultural context of people's behavior. In this case the family moral empowerment is the tip of the spear.

Bad factor of an institution of the family be a part of criminogenic social deviation. Family poor discipline, parent negligence, as well as indifference to strengthen the consistency of deviation from family members, especially children. Thus, in the context of prevention cyberporn, family empowerment policy is needed, in the form of:

First, Economic Context. Low-income families tend to have social class pressure, which determines poor housing, low quality education, and social environment that then raises criminogenic factor.

Second, Quality of Family Head. Failure and indifference to family members cause a huge effect on crime. The moral quality of family head as parents need to be refreshed through family counseling program. Failed family education will cause family members, especially children to seek support of the primary group peers, so it is very easily influenced.

Third, Custody. Efforts to reconsider the custody of parents who become criminals. The crimes committed by the parents will result in a bad family interaction, such parents will edu- cate family members with a bad attitude, or inconsistent discipline will be a crucial determinant of deviant behavior. ${ }^{16}$

Some forms mentioned above can be used as a benchmark for social policy in the institution of the family. Establishing a good family structure and moral, as subcultural expectations that emphasizes community involvement in crime prevention cyberporn is required. The family relationship is the foundation of social beginning since a good family to be able to communicate the basic personality and mentality that comply with the norm by the assertion that the family is able to provide custom hallmark of morality. Individual consideration on morally mature in the family will affect the social situation in the neighborhood. The cumulative effect is a rule adjustment of external conditions as variable affected. Therefore, the participation rate of crime prevention through the family is very important to prepare the public legal compliance.

The Government has a big share in achieving the concept of the family institution. Moreover, the family development launched by the government in efforts to achieve quality family who live in a healthy environment through Law Number 52 Year 2009. The Law implies embodiment of quality family in physical and nonphysical aspects which include health status, education , employment, productivity, social level, resilience, self-reliance, intelligence, as a basic measure to develop skills and enjoy life as a human being cautious, culture, personality, nationality and a decent life is the responsibility of the Government and the Provincial Government. The Law is a remarkable instrument, although optimization is still not perceived by people, particularly families.

\section{Education and Cyberporn Prevention}

Formal education in educational institutions is a stigma that affects, causes or prevent irregularities. Building a principle of individual

\footnotetext{
16 Tri Suyatno, "Pengaruh Pornografi Terhadap Perilaku Belajar Siswa (Studi Kasus: Sekolah Menengah X)", Jurnal: Pendidikan Dompet Dhuafa, Vol. 1 No. 1, 2011, Bogor: Pusat Sumber Belajar Divisi Pendidikan Dompet Dhuafa, page 12 .
} 
morality by involving the role of formal education is seen as a subjective experience in depth the social behavior. Education contributes to the changing conditions in society. Practices or understanding in society, by education can be developed into a belief in social action and the object world that combines nature and condition of individual behavior daily. Pornographic contents widely spread in schools, targeting unstable adolescents, therefore, it needs assistance and awareness for students to prevent them from deviant behavior.

Hence, the role of education in society dimension is important in shaping social attitudes of individuals. Non-favorable formal educational environment will create irregularities. First cause, the environmental factors that are less familiar school meals moral values, so that the individual has only intellectual ambition minus morality. Second, cyberporn as the impact of technological development will continue increasing with higher education. Education that teaches people to be open with access to technology is an easy target for the spread of pornography via the Internet.

Favorable educational environment teaching about moral applied by formal educational institutions will greatly help an individual character better. The process of enculturation, socialization, institutionalization and internalization will be more quickly absorbed into individual's mind. This will certainly revives the spiritual ideal of the individual. Thus forming akhlakul karimah will create a solid attitude to the situation without having a cultural shift contrary to the prevailing norms. Therefore, the principles of reward is not only a benefit to the benchmark logical-mathematical, which position the individual person as first-class citizens. Yet the moral and spiritual education is also the orientation that should not be ruled out.

Conditions formal education cannot be ignored. Internalization behavior can be done by educating the public about cybercrime, especially cyberporn ${ }^{17}$. The formation of these charac-

17 Nancy E Marion, "The Council of Europe's Cyber Crime Treaty: An exercise in Symbolic Legislation", Interna- ters should be returned to the national education system which has actually been set. Increased religious aspect is very important given to learners. Although some studies have suggested their inverse ratio between religious attitudes with cyberpon, the authors criticize the results of these studies ${ }^{18}$ because researchers only use one form of religion in forming a hypothesis that does not correlate objective. The author believes the government should firmly reform education providers who only a few touches of moral values and religion in the learning system. Thus a good formal education and promoting the values and norms as well as common sense would make the world of education as a cure in determining the behavior of individual cultures.

\section{Conclusion}

Cyberporn prevention policy requires legal supports such as the arrangement of the public awareness on the concept of legal culture change that involves forms of variation of life as theoretical base cyberporn crime prevention. Cyberporn basically contradicts the norms and culture of the people. Therefore cyberpon can be overcome by strengthening moral and legal culture of society that can return the consent form or variation in life. In developing the legal system in Indonesia one of its forms is the order of a society to encourage the development of laws that reflect the life of society itself.

\section{Suggestion}

Restructuring of community development programs can be pursued through the moral and religious approaches as well as the education community behavior. Moral and religious approach is a strategic approach because it can effectively reduce the potential for accessing pornography, and will be able to raise people awareness to avoid pornography, regardless of

tional Journal of Cyber Criminology, Vol. 4 No. 1-2, January 2010, page 699.

18 Jesse W Abell, Timothy A Steenbergh, Michael J. Boivin, "Cyberporn Use In The Context Of Religiosity", Journal of Psychology and Theology, Vol. 34 No. 2, June 2006, California: Biola University, page 165. 
type and medium. The concept of crime prevention to reduce or eliminate the causes of such crimes would prevent such crimes recur.

\section{References}

Abell, Jesse W. Timothy A Steenbergh. Michael J. Boivin. "Cyberporn Use In The Context Of Religiosity". Journal of Psychology \& Theology. Vol. 34 No. 2. June 2006. California: Biola University;

Aryani, Kandi. "Analisis Penerimaan Remaja Terhadap Wacana Pornografi Dalam Situs-Situs Seks Di Media Online". Jurnal Masyarakat Kebudayaan dan Politik. Vol/Year XIX. No. 2. 2006. Surabaya: Faculty of Social and Political Science Universitas Airlangga;

Brizendine, Louann. "Penulis buku The Male Brain" (E-Harmoni staff. Inside "The Male Brain'). Available on http://www.ehar mony.com accessed on April 20 $0^{\text {th }}$ 2015;

Bunga, Dewi. "Penanggulangan Pornografi dalam Mewujudkan Manusia Pancasila". Jurnal Konstitusi. Vol. 8 No. 4. 2014. Jakarta: Mahkamah Konstitusi;

Cavaglion, Gabriel. "Cyber-porn Dependence: Voices of Distress In An Italian Internet Self-Help Community". International journal of mental health and addiction. Vol. 7. No. 2. April 2009. Auckland University of Technology; West Virginia University. Dept. of Behavioral Medicine \& Psychiatry. Springer Verlag;

Dako, Amirudin Y. "Pengaturan hukum Tindakan Teknologi Pornografi Melalui Akses Media Internet". Jurnal Legalitas. Vol. 2. No. 3. 2009. Gorontalo: Department of Law Universitas Negeri Gorontalo;

Darmawan, Muhammad Kemal. "Pencegahan Kejahatan: Dari Sebab-Sebab Kejahatan Menuju Pada Konteks Kejahatan". Jurnal Kriminologi Indonesia. Vol. 1 No. 3. July 2012. Jakarta: Department of Criminology Faculty of Social and Political Sciences Universitas Indonesia;

Fisher, Robert J and Gion Green. 1998. Introduction to Security. USA: Elsevier Science USA. Butterworth Heinemann;

Hagan, Frank. 2013. Pengantar Kriminologi: Teori. Metode. dan Perilaku Kriminal. Jakarta: Kencana Prenada Media Group;
J.R. and M.M.S. Maturing brain flips function of amygdala in regulating stress hormones. The Journal of Neuroscience. Vol. 34 No. 34. August 2014. Washington: Stanford University's;

Marion, Nancy E. "The Council of Europe's Cyber Crime Treaty: An exercise in Symbolic Legislation". International Journal of Cyber Criminology. Vol. 4 No. 1-2. January 2010;

Novita. "Budaya Hukum Cyberporn di Semarang". Jurnal Pandecta (research law journal). Vol. 7 No. 2. July 2012. Semarang: Faculty of Law Universitas Semarang;

Rachmawati, Dian. "Phising Sebagai Salah Satu Bentuk Ancaman Dalam Dunia Cyber". Jurnal SAINTIKOM. Vol. 13 No. 3. September 2014. Medan: STMIK Triguna Dharma;

Risman, Elly. Mark B Kastleman. Randall F Hyde. Malik B Badri. "Membangun Kesadaran Betapa Dahsyatnya Kerusakan Kesehatan Otak Akibat Perilaku Adiksi Pornografi". Pidato Seminar. International Seminar and Workshop. Jakarta. Hotel Grand Kemang. Monday 27 September 2014;

Sabina, Chiara. Janis Wolak and David Finkelhor. "The Nature and Dynamics of Internet Pornography Exposure for Youth. Journal of CyberPsychology \& Behavior". Vol. 11 No. 6. December 2008. USA: Mary Ann Liebert. inc.;

Setiadi, Mas Wigrantoro Roes. Budaya pornografi di Indonesia. Available on https:// www.selasar.com. Accessed on November $30^{\text {th }}$ 2015;

Suyatno, Tri. "Pengaruh Pornografi Terhadap Perilaku Belajar Siswa (Studi Kasus: Sekolah Menengah X)". Jurnal: Pendidikan Dompet Dhuafa. Vol. 1 No. 1. 2011. Bogor: Pusat Sumber Belajar Divisi Pendidikan Dompet Dhuafa;

Zakaria, Alfons. "Pelarangan Website Yang Bermuatan Pornografi di Indonesia (The Restriction of Websites Containing Pornography Materials in Indonesia". Risalah Hukum: Jurnal Hukum. Vol. 7 No. 1. June 2011. Samarinda: Faculty of Law Universitas Mulawarman. 